\title{
Surface Species Formed during Methane Oxidation over Some Rare Earth Elements Oxides
}

\author{
Mohammad Ateeq Al-Dosari \\ National Nanotechnology Research Center, King Abdul Aziz City for Science and Technology (KACST), Riyadh, KSA \\ Email: aldosari@kacst.edu.sa
}

How to cite this paper: Al-Dosari, M.A. (2018) Surface Species Formed during Methane Oxidation over Some Rare Earth Elements Oxides. Green and Sustainable Chemistry, 8, 1-18.

https://doi.org/10.4236/gsc.2018.81001

Received: November 6, 2017

Accepted: December 25, 2017

Published: December 28, 2017

Copyright $\odot 2018$ by author and Scientific Research Publishing Inc. This work is licensed under the Creative Commons Attribution International License (CC BY 4.0).

http://creativecommons.org/licenses/by/4.0/

\section{(c) (i) Open Access}

\begin{abstract}
This study has compared the ability of paramagnetic element oxides i.e. $\mathrm{Pr}$, $\mathrm{Eu}, \mathrm{Yb}$ in catalyst oxidation of methane. These have been prepared by precipitation, and then calcined at $600^{\circ} \mathrm{C}$ to get $\mathrm{M}_{2} \mathrm{O}_{3}$. Methane was then passed through a disk in $\mathrm{KBr}$, and the reactions were conducted at room temperature; $200^{\circ} \mathrm{C}$ and then $300^{\circ} \mathrm{C}$. The reaction products were then identified by F.T.I.R spectroscopy. It was observed that these oxides have extracted the protons from methane and the $\mathrm{CH}_{3}{ }^{\circ}$ radicals were evidently formed. This focused radical react further to give $\mathrm{CH}_{3} \mathrm{O}, \mathrm{C}_{2} \mathrm{H}_{6}$ and the formation of Propionic acid is reported as one of the catalytic reaction products. The study also indicated the presence of aromatic products and in some instances, phenol was identified. Thereafter, the mechanism of the reaction was envisaged. For all the catalysts the conversion increases relatively with increasing the reaction temperature. The study can deduce that these oxides have the same ability as those of high paramagnetic properties to extract the proton, but the products are trapped and react further on the surface of the oxide.
\end{abstract}

\section{Keywords}

Oxidative Coupling of Methane, Partial Oxidation, Lanthanide Oxides, I.R. Study

\section{Introduction}

Due to the noticeable decrease of oil reserves and high oil prices globally, and protecting the Earth from the gaseous pollutants and global warming, attention has been directed to search for alternatives to oil, primarily natural gas (methane) to produce chemicals and fuels cleaner and more environmental-friendly 
and economic value added, to maintain global economic growth and fuel supplies, through research and development programs designed to convert methane to hydrocarbons, an economically feasible ways that directly or indirectly as a process of oxidative coupling of methane (OCM) [1]-[6].

It is industrially important to convert alkanes $C_{1}-C_{4}$ to oxygenated compounds, which can be used as raw materials for industries. Despite the fact that these transformations favored heat, the problem of industries lies in finding the appropriate operational conditions to generate intermediates containing active and strong $\mathrm{C}-\mathrm{H}$ or $\mathrm{C}-\mathrm{C}$ bonds, compared to oxidation of the alkanes to carbon dioxide $\mathrm{CO}_{2}$ and water $\mathrm{H}_{2} \mathrm{O}$.

The oxidative coupling of methane (OCM) is one of the most important reactions in relation to chemical utilization of natural gas. Since pioneering works of Keller et al. [7], many studies have been made to find an efficient catalyst. In this area, catalysts based upon lanthanide oxide have been shown to have significance, but as yet largely unrealized potential for catalyzing the oxidation of methane [8]-[17].

However, it has been found in a series of catalytic oxidation that the catalytic activity of the lanthanide oxides significantly differs from each other. Sazonov et al. [18] compared the catalytic activity in the oxidation of hydrogen and propylene with that of the isotopic exchange of oxygen, and suggested that the catalytic activity depends on the binding energy of oxygen to the surface and on the valance of the lanthanide ions. Others suggested that the catalytic activity of the lanthanide oxides depends on the electronic configuration of the inner $4 f$ subshell [19].

Considerable progress has been made in understanding the mode by which methane is activated for the oxidative addition to metal centers and for the generation of methyl radicals $\mathrm{CH}_{3}$, that are formed at the surface of the catalyst [20]. Which eventually changes at high temperature to both oxygen compounds (methanol and formaldehyde), and to higher hydrocarbons (mainly ethane, ethylene) [21] [22] [23] [24].

Wang et al. [25] reported that methane could be transformed to benzene on transition metal ions supported by HZSM-5 catalysts under non-oxidative condition. This study as Keller et al. and Driscoll et al. [7] [26] proposed a mechanism for the oxidative coupling of $\mathrm{CH}_{4}$ over metal oxides, in which methyl radicals $\mathrm{CH}_{3}{ }^{\circ}$ formed into the gas phase through a surface reaction coupled on the surface to form ethane. While the formation of the surface-generated methyl radicals is an accepted part of both mechanisms, it remains to be demonstrated whether subsequent surface reactions or gas-phase reactions of the methyl radicals constitute the major pathway for the oxidative coupling of methane.

$\mathrm{Wu}$ et al. [27], suggested that, Lanthana, gave a methane conversion with a high selection toward $\mathrm{C}_{2}{ }^{+}$, and an oxide interaction provided the formation of additional oxygen vacancies which exhibited higher selectivity to $\mathrm{C}_{2} \mathrm{H}_{4}$. Several 
papers [28] [29] [30], examined the abilities of the lanthanide oxides to catalyze the oxidative coupling of $\mathrm{CH}_{4}$ to form $\mathrm{C}_{2} \mathrm{H}_{6}$ and $\mathrm{C}_{2} \mathrm{H}_{4}$ Scheme 1 .

There is no conclusive evidence of any duplication of methyl free radicals on the surface of heterogeneous or heterogeneous catalysts that lead to $\mathrm{C}_{2} \mathrm{H}_{6}$ and $\mathrm{C}_{2} \mathrm{H}_{4}$, but it is expected that this may be due to the formation of methyl free radicals in the gas phase on the catalyst surface, later mating $\mathrm{C}_{2} \mathrm{H}_{6}$, or enter into a series of successive surface reactions that eventually lead to full oxidation [31] [32] [33] [34].

Methyl radicals react extensively with the lanthanide-metal oxides $\mathrm{CeO}_{2}$, $\mathrm{Pr}_{6} \mathrm{O}_{11}$, and $\mathrm{Tb}_{4} \mathrm{O}_{7}$ which have multiple cationic oxidation states [35] [36]. By contrast, the oxides $\mathrm{La}_{2} \mathrm{O}_{3}, \mathrm{Nd}_{2} \mathrm{O}_{3}, \mathrm{Sm}_{2} \mathrm{O}_{3}, \mathrm{Eu}_{2} \mathrm{O}_{3}$, and $\mathrm{Yb}_{2} \mathrm{O}_{3}$ react with $\mathrm{CH}_{3}{ }^{\circ}$ radicals to only a small extent. Consistent with this observation, the former group of oxides is ineffective in the generation of $\mathrm{CH}_{3}{ }^{\cdot}$ radicals which emanate into the gas phase.

Catalytic studies with a series of rare earth oxides have been undertaken to observe the effect of periodic trends in basicity and cationic 4f-electron configuration. It is known that high surface basicity of catalyst is necessary to enhance the $\mathrm{C}_{2}$ selectivity and improve the catalytic performance of the metal oxides, for oxidative coupling of methane (OCM) [37]-[42]. The catalytic activity of lanthanide oxides for oxidative coupling of methane showed maxima at $\mathrm{Sm}, \mathrm{Gd}$, and Ho oxides. A different activity pattern was ascribed to the difference in the sample source and in the pretreatment of samples [43].

The importance of the specific surface area of the catalyst was pointed out in oxidative coupling of methane. Tagawa et al. [44] demonstrated that, an amorphous $\mathrm{LnAlO}_{3}$ catalyst shows a high activity for the $\mathrm{C}_{2}$ hydrocarbon formation. The active sites were concluded to be formed on the surface of an amorphous phase, because the catalytic activity decreased with the growth of the crystalline perovskite phase [45].

The $\mathrm{C}_{2}$ hydrocarbon formation rate is proportional to the increase in lanthanide ionization potentials. This suggests that the basicity of the lanthanide, or the tendency to lose anions, is closely related to the formation of the active sites on the catalyst surface [46] [47] [48] [49]. Temperature-programmed adsorption studies on a series of catalysts indicated that oxygen molecules were
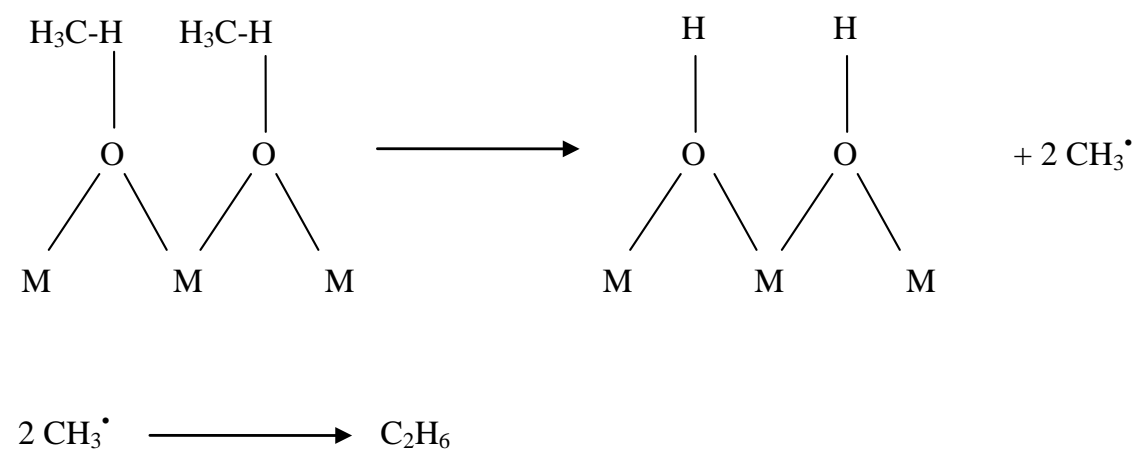

Scheme 1. Surface generated gas-phase $\mathrm{CH}_{3} \cdot$ radical. 
desorbed from the catalyst during the heating with reaction temperature, and two kinds of oxygen adsorption sites were characteristic of the active amorphous catalysts, Which is thought to be responsible for the coupling reaction [50].

In the oxidative coupling of methane reaction catalyzed by metal oxide, the transfer of oxygen to the surface from bulk or gas phase is very important in its catalytic activity, because the abstraction of hydrogen from methane is caused by an oxygen ion present on the surface of metal oxide catalyst [51] [52] [53]. However, an OCM catalyst acts not only as the radical initiator but also as the radical quencher.

In this study, we will try to identify the species formed on the surface of the catalyst during the coupling reaction, leading to products with added economic value.

\section{Experimental Methods}

\subsection{Materials and Catalyst Preparation}

\subsubsection{Materials}

Main materials used in the experiment were of high purity:

- Methane gas $\mathrm{CH}_{4}(99.95 \%)$ Air products England.

- Praseodymium Chloride (99.9\%).

- Europium Chloride (99.9\%).

- Ytterbium Nitrate (99.9\%) (Oxidized).

- Distilled water.

- Ammonium solution (sp. gr. $0.91 \mathrm{gm} / \mathrm{ml}$, about 25\% $\mathrm{NH}_{3}$ ) BDH Analar BDH chemicals ltd. Poole, England.

- Hydrochloric acid (sp. gr. $1.18 \mathrm{gm} / \mathrm{ml}$, about 36\% $\mathrm{HCl}$ ) BDH Laboratory Reagents.

\subsubsection{Equipment}

- Thermolyne (a subsidiary of Syron) Type 1500 Furnace.

- Disc maker (Perkin Elmer) Pressurized up to 15 Tons $/ \mathrm{cm}^{2}$.

- F.T.I.R Spectrophotometer (Perkin Elmer) Model 1600.

- Vacuum line.

Oxides of transition metals (rare earth) would be prepared as described in the literature in pure forms. However, mixed oxides would be prepared by co-precipitation of the appropriate mixture of metal chlorides or nitrates by alkaline solutions. This method (co-precipitation) is often used to prepare oxidic or sulfidic catalysts. A solution of a metal salt (often the nitrate) is combined with an ammonium salt of a suitable anion to precipitate the metal ion as hydroxide, sulfide, oxalate, carbonate... etc. Upon heating to high temperatures (calcinations) the compounds are decomposed to give correspondent metal oxides. Simultaneous addition of the metal salt and the precipitating agent to the precipitation flask gives a more uniform catalyst composition than the sequential addition of the components [54]. 
Accordingly, about 5 grams of chlorides or nitrates of lanthanide (rare earth) metals were accurately weighed, and dissolved in a minimal volume of distilled water. Few drops of $\mathrm{HCl}(1 \mathrm{~N}, \mathrm{pH}=6-6.5)$ were added to the chloride solution, which was slightly cloudy, in order to render such solution completely clear. Lanthanide hydroxides were precipitated by addition of a slightly stoichiometric excess of a dilute aqueous ammonia solution or sodium hydroxide. The resulting gelatinous suspension was allowed 24 hours for coagulation and settling of the precipitate. Before filtration of the resulting precipitate, the mixture was heated to boiling for one hour to change the form of precipitate from gelatinous to a finely powdered granular form.

Filtration was performed on a Buchner funnel (No. 5) under vacuum for 20 hrs, the filter cake was washed with boiling distilled water $(5 \times 5 \mathrm{ml})$, collected and dried in an oven at $600^{\circ} \mathrm{C}$ for $20 \mathrm{hrs}$.

Ultimately, lanthanide oxides were obtained and the brittle Praseodymium oxide color was changed from pale green to dark brown. Remaining oxides were fluffy porous and changed from white to light yellow. Yield: 3 grams (60\%).

A sample of the metal oxide $(0.025 \mathrm{gm})$ was thoroughly milled into a fine powder with 10 times its weight of $\mathrm{KBr}$. The resultant powder was pressed into a disc using a disc maker, and a pressure equivalent to 10 ton load.

The resulting disc was exposed to a gas stream of hydrocarbons (e.g. methane gas) $\left(22 \times 10 \mathrm{~cm}^{3} / \mathrm{min}, 1.2\right.$ atoms $)$, with intervals of one hour each at a thermal gradient starting from ambient temperature to about $185^{\circ} \mathrm{C}-195^{\circ} \mathrm{C}, 200^{\circ} \mathrm{C}$ $215^{\circ} \mathrm{C}$ and $250^{\circ} \mathrm{C}-260^{\circ} \mathrm{C}$, temperature control was done manually.

The infrared spectrum of the lanthanide oxide disc was measured before changing the temperature, to elucidate any reaction that could occur, between the metal oxide and methane, during the flow of methane over the metal oxide (catalyst), as follows:

\subsubsection{At $25^{\circ} \mathrm{C}$ (Ambient Temperature)}

The disc was heated to $110^{\circ} \mathrm{C}$ to evaporate any water vapor that may be present on the surface of the disc. After cooling to ambient temperature the infrared spectrum was measured, to ensure the absence of water or any other adsorbed substances on the surface of the disc. Methane gas was passed over the sample for one hour, and the infrared spectrum of the disc was measured (by F.T.I.R. Spectrophotometer (Perkin Elmer) model 1600). The spectrum showed that the disc contained new species. A sample of the expected species (e.g. phenol) was grinded with the same weight of the metal oxide and potassium bromide and measurement of the infrared spectrum was repeated. The two spectra were compared and both proved to contain the same species indicating that the reaction product consisted of phenol.

\subsubsection{At Other Temperatures}

The reaction disc was heated to a temperature higher than the boiling point of the expected species $\left(t>185^{\circ} \mathrm{C}\right)$, grinded, pressed under the same pressure and 
the spectrum was remeasured to assure the absence of any reaction species. The gas was passed over the disc for one hour, at $185^{\circ} \mathrm{C}-195^{\circ} \mathrm{C}$, and after cooling at room temperature, the I.R. spectrum was measured. The process was repeated at $200^{\circ} \mathrm{C}-215^{\circ} \mathrm{C}$ and $250^{\circ} \mathrm{C}-260^{\circ} \mathrm{C}$ and the resulting spectra showed that at temperature lesser than the boiling point $\left(t>185^{\circ} \mathrm{C}\right)$ of expected species the same products were produced.

\section{Results and Discussion}

In a separate set of experiments, methane has been adsorbed on the surface of the three oxides $\left(\mathrm{Pr}_{2} \mathrm{O}_{3}, \mathrm{Eu}_{2} \mathrm{O}_{3}, \mathrm{Yb}_{2} \mathrm{O}_{3}\right)$ at room temperature, and at elevated temperatures respectively, at a pressure of ca $1.2 \mathrm{~atm}$. for one hour. The F.T.I.R spectra of each disc have been recorded after evacuation at room temperature. The spectra are presented in Figures 1-4.

A close investigation of the spectra indicates that the three oxides are relatively similar in behavior under the specified comparable conditions. Hence, anyone could be used as a prototype of the other two oxides. This would give a comparative study that could be used as the basis of a generalized phenomenon.

The infrared spectrum region between 4000 and $200 \mathrm{~cm}^{-1}$ can roughly be divided into deferent regions:

1) The $\mathrm{X}-\mathrm{H}$ stretch region $\left(4000-2500 \mathrm{~cm}^{-1}\right)$, where strong contributions of $\mathrm{OH}, \mathrm{NH}, \mathrm{CH}$ and $\mathrm{SH}$ stretch vibrations are observed.

2) The triple bond region $\left(2500-2000 \mathrm{~cm}^{-1}\right)$, where contributions from gas phase CO $\left(2143 \mathrm{~cm}^{-1}\right)$ and linearly adsorbed CO $\left(2000-2200 \mathrm{~cm}^{-1}\right)$ are seen.

3) The double region $\left(2000-1500 \mathrm{~cm}^{-1}\right)$, where in catalytic studies bridge

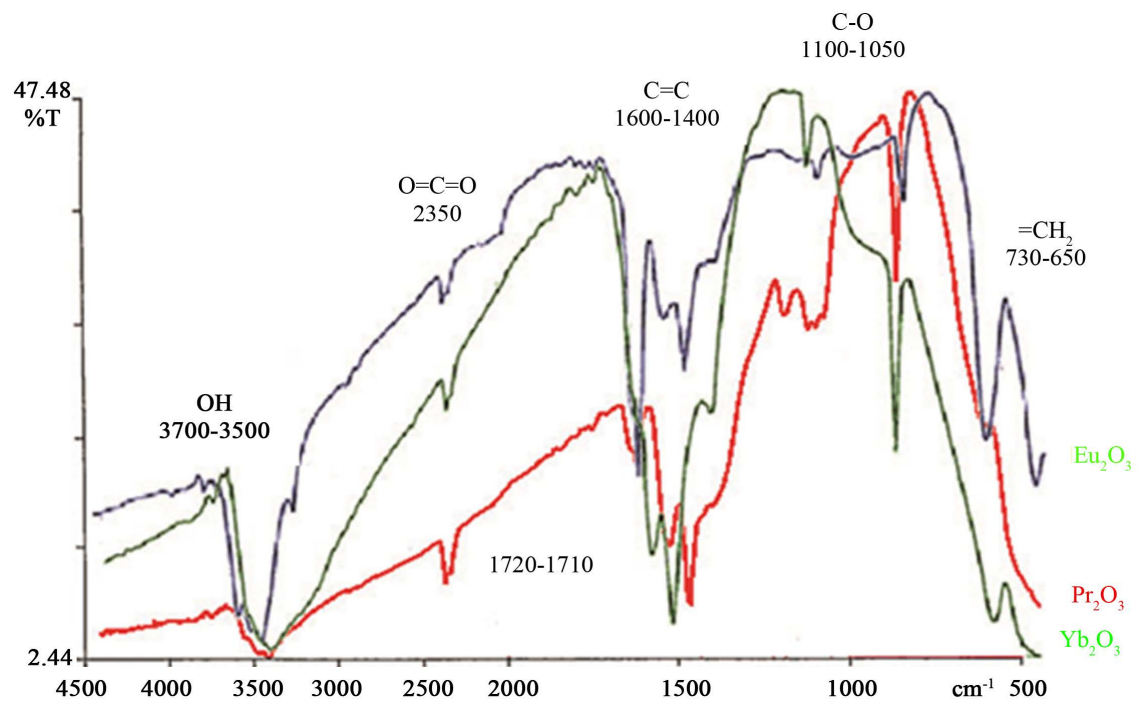

Figure 1. Infrared absorption spectra of surface species, between 4000 and $200 \mathrm{~cm}^{-1}$ formed by adsorption of methane over $\operatorname{Pr}_{2} \mathrm{O}_{3}, \mathrm{Eu}_{2} \mathrm{O}_{3}$ and $\mathrm{Yb}_{2} \mathrm{O}_{3}$ at Room Temperature. These have been prepared by precipitation, and then calcined at $600^{\circ} \mathrm{C}$ to get $\mathrm{M}_{2} \mathrm{O}_{3}$. Methane was then passed through a disk in $\mathrm{KBr}$. at room temperature, and at elevated temperatures respectively, at a pressure of ca $1.2 \mathrm{~atm}$. and for one hour. 


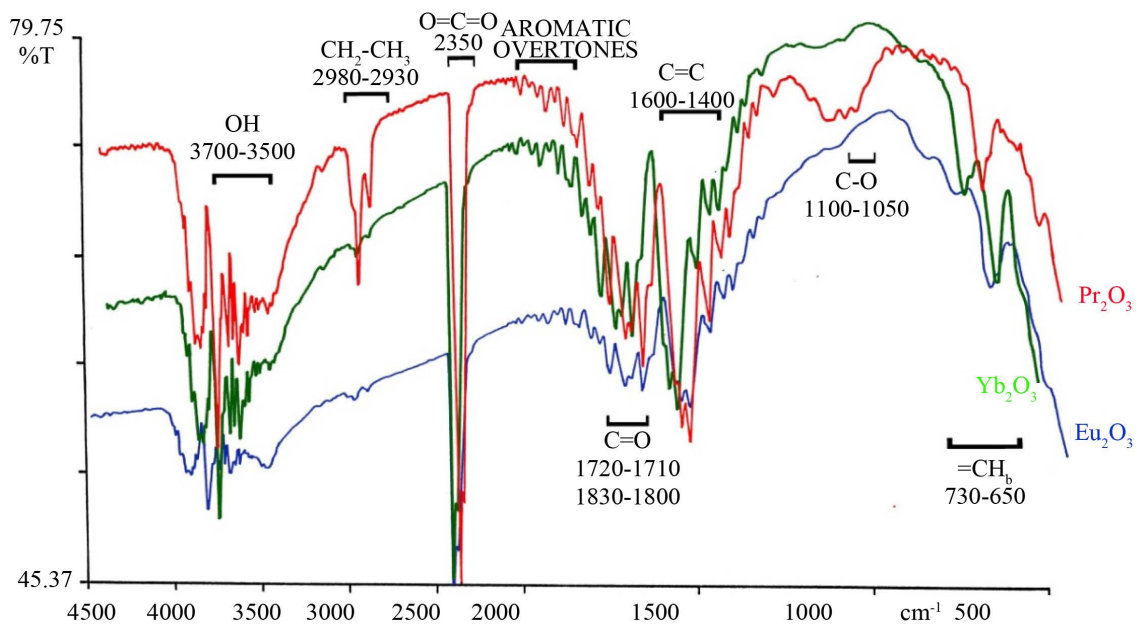

Figure 2. Infrared absorption spectra of surface species, between 4000 and $200 \mathrm{~cm}^{-1}$ formed by adsorption of methane over $\mathrm{Pr}_{2} \mathrm{O}_{3}, \mathrm{Eu}_{2} \mathrm{O}_{3}$ and $\mathrm{Yb}_{2} \mathrm{O}_{3}$ at $185^{\circ} \mathrm{C}-195^{\circ} \mathrm{C}$. These have been prepared by precipitation, and then calcined at $600^{\circ} \mathrm{C}$ to get $\mathrm{M}_{2} \mathrm{O}_{3}$. Methane was then passed through a disk in $\mathrm{KBr}$. at room temperature, and at elevated temperatures respectively, at a pressure of ca $1.2 \mathrm{~atm}$. and for one hour.

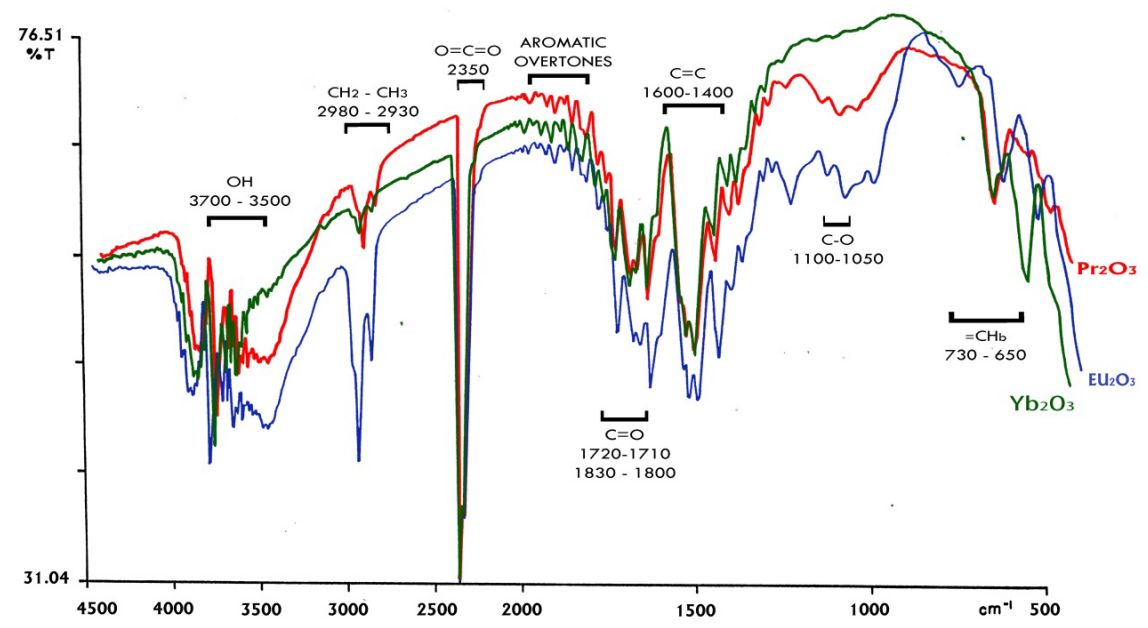

Figure 3. Infrared absorption spectra of surface species, between 4000 and $200 \mathrm{~cm}^{-1}$ formed by adsorption of methane over $\mathrm{Pr}_{2} \mathrm{O}_{3}, \mathrm{Eu}_{2} \mathrm{O}_{3}$ and $\mathrm{Yb}_{2} \mathrm{O}_{3}$ at $200^{\circ} \mathrm{C}-215^{\circ} \mathrm{C}$. These have been prepared by precipitation, and then calcined at $600^{\circ} \mathrm{C}$ to get $\mathrm{M}_{2} \mathrm{O}_{3}$. Methane was then passed through a disk in $\mathrm{KBr}$. at room temperature, and at elevated temperatures respectively, at a pressure of ca 1.2 atm for one hour.

bonded CO, as well as carbonyl groups in adsorbed molecules (around 1700 $\mathrm{cm}^{-1}$ ).

4) The fingerprint region $\left(1500-500 \mathrm{~cm}^{-1}\right)$, where all single bonds between carbon and elements such as nitrogen, oxygen, sulphur and halogens are adsorbed.

5) The M-X or metal-adsorbate region (around $450-200 \mathrm{~cm}^{-1}$ ), where the metal-carbon, metal-oxygen and metal-nitrogen stretch frequencies in the spectra of adsorbed species are observed. 


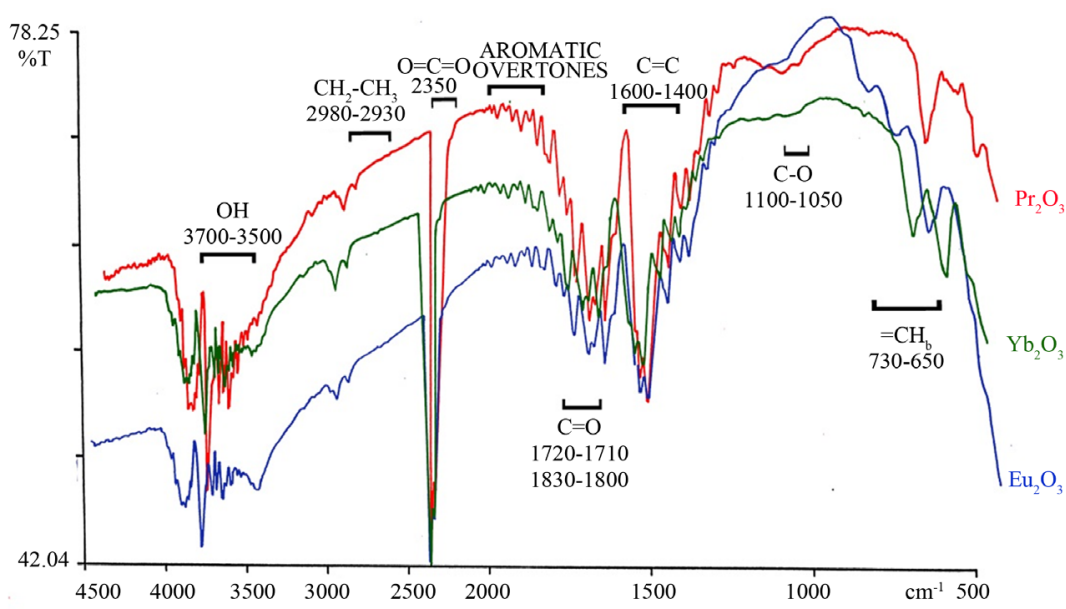

Figure 4. Infrared absorption spectra of surface species, between 4000 and $200 \mathrm{~cm}^{-1}$ formed by adsorption of methane over $\mathrm{Pr}_{2} \mathrm{O}_{3}, \mathrm{Eu}_{2} \mathrm{O}_{3}$ and $\mathrm{Yb}_{2} \mathrm{O}_{3}$ at $250^{\circ} \mathrm{C}-260^{\circ} \mathrm{C}$. These have been prepared by precipitation, and then calcined at $600^{\circ} \mathrm{C}$ to get $\mathrm{M}_{2} \mathrm{O}_{3}$. Methane was then passed through a disk in $\mathrm{KBr}$. at room temperature, and at elevated temperatures respectively, at a pressure of ca $1.2 \mathrm{~atm}$. for one hour.

\subsection{0 - $3000 \mathrm{~cm}^{-1}$ Region}

In the segment $4000-3000 \mathrm{~cm}^{-1}$, several infrared bands show up. Mainly, we can see the following bands:

Free $(\mathrm{OH})$ group absorbed at $3750 \mathrm{~cm}^{-1}$, while with bonded $(\mathrm{OH})$ group, vibrates at $3650 \mathrm{~cm}^{-1}$. However, to distinguish between the $(\mathrm{OH})$ group and $\left(\mathrm{H}_{2} \mathrm{O}\right)$ molecule adsorbed on the surface of the oxide, we should look at the 3880 - 3300 $\mathrm{cm}^{-1}$ region; where $(\mathrm{OH})$ stretch of water absorbs at $3450 \mathrm{~cm}^{-1}$ and shows marked evidence of hydrogen bonding [55] [56].

Methane adsorbed on $\mathrm{Al}_{2} \mathrm{O}_{3}$ shows the following bands in the region under consideration [57], 3785, 3740,3710 $\mathrm{cm}^{-1}$ and it is indicative that the band at $3785 \mathrm{~cm}^{-1}$ is due to hydrogen bonding. However, it is worthy to mention that band at $3750 \mathrm{~cm}^{-1}$ (width of $15 \mathrm{~cm}^{-1}$ ) is due to $(\mathrm{O}-\mathrm{H})$ stretch of the free hydroxyl group and the lower shift is due to hydrogen bonding. For example, in silica we get a band at $3770 \mathrm{~cm}^{-1}$ assigned to free $(\mathrm{O}-\mathrm{H})$ and a broadband at $3450 \mathrm{~cm}^{-1}$ due to hydrogen bonding.

In alkylation of hydroxylated surfaces the band at $3750 \mathrm{~cm}^{-1}$ decreases and bands at 2965 and $2862 \mathrm{~cm}^{-1}$ increases. The shift in the $3750 \mathrm{~cm}^{-1}$ band due to the hydrogen bonding is exemplified by the following two examples (Table 1).

The infrared spectra of all the oxides show, invariably, and at all elevated temperatures, sharp adsorption bands at: $3882,3835,3741,3612,3448 \mathrm{~cm}^{-1}$, which according to our above discussion is a conclusive evidence of the presence of free and hydrogen bonded hydroxyl groups. The band at $3448 \mathrm{~cm}^{-1}$ is assignable to $(\mathrm{OH})$ stretch of water and also shows marked evidence of hydrogen bonding. Hence, one could envisage the following mechanism:

1) Formation of H-bonded hydroxyl group on the surface of the oxide (Scheme 2). 
Table 1. The shift in the $3750 \mathrm{~cm}^{-1}$ band due to the hydrogen bonding.

\begin{tabular}{ccc}
\hline H-bonding with & Frequency of $(\mathrm{OH}) \mathrm{cm}^{-1}$ & Displacement $\mathrm{cm}^{-1}$ \\
\hline Oxygen & 3737 & 33 \\
Methane & 3717 & \\
\hline
\end{tabular}

Scheme 2. Formation of H-bonded hydroxyl group on the surface of the oxide.

2) Formation of a free hydroxyl group and $\mathrm{CH}_{3}{ }^{\circ}$ radicals (Scheme 3).

3) Formation of free and hydrogen bonded water (Scheme 4 and Scheme 5).

In the same infrared spectral region of $4000-3000 \mathrm{~cm}^{-1}$, we expected to see the following stretching frequencies, $=\mathrm{CH}_{2}$ at $3030 \mathrm{~cm}^{-1}, \equiv \mathrm{CH}$ at 3300 $\mathrm{cm}^{-1}$. However, such bands have not been observed and hence have been excluded as part of the reaction products under these conditions of reaction.

When we consider the $3000-2500 \mathrm{~cm}^{-1}$ region we find the following possible absorptions: The $\left(-\mathrm{CH}_{3}\right)$ group give rise to a symmetrical $(\mathrm{C}-\mathrm{H})$ stretch invariably falling between $2850-2890 \mathrm{~cm}^{-1}$, and an asymmetrical stretching frequency at $2940-2980 \mathrm{~cm}^{-1}$ [56]. On the other hand the $\left(-\mathrm{CH}_{2}^{-}\right)$group gives rise to a band at $2930 \mathrm{~cm}^{-1}$ assigned to the asymmetrical (C-H) stretch and another at $2860 \mathrm{~cm}^{-1}$ assigned to the symmetrical stretch [58].

The results shown by different oxides exhibit bands at 2965, 2961 and 2855 $\mathrm{cm}^{-1}$ [59]. These have been assigned to an alkoxy group formation as indicated by the mechanism shown by Scheme 5 . The specifications of such an alkoxy group will be given later in the discussion.

\subsection{0 - $2000 \mathrm{~cm}^{-1}$ Region}

The infrared absorption bands anticipated at the $2500-2000 \mathrm{~cm}^{-1}$ region are:

- The $(\mathrm{O}=\mathrm{C}=\mathrm{O})$ asymmetrical stretch at $\sim 2330 \mathrm{~cm}^{-1}[60]$,

- The $(-\mathrm{C} \equiv \mathrm{C}-)$ stretch,

o Terminal (-C $\equiv \mathrm{C}-)$ shows weak band $2140-2050 \mathrm{~cm}^{-1}$.

o Non-terminal shows at $2300-2050 \mathrm{~cm}^{-1}$.

o An unsymmetrical disubstituted acetylenes exhibit infrared band at 2260 $2190 \mathrm{~cm}^{-1}$ variable intensity.

- The stretching bands of (-C $\equiv \mathrm{C}-)$ are absent in symmetrically disubstituted acetylenes (alkynes) or acetylene.

- The intensity of the $(-\mathrm{C} \equiv \mathrm{C}-)$ stretching bands is increased by conjugation with a carbonyl group.

The infrared spectra of the absorbed methane show strong I.R. absorption 


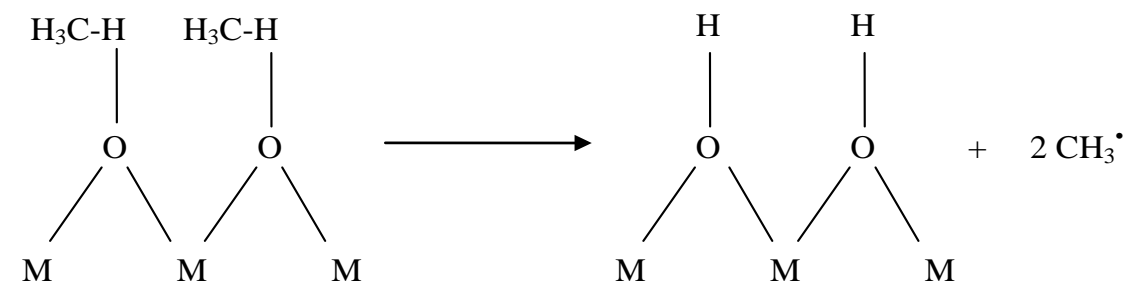

Scheme 3. Formation of free hydroxyl group.

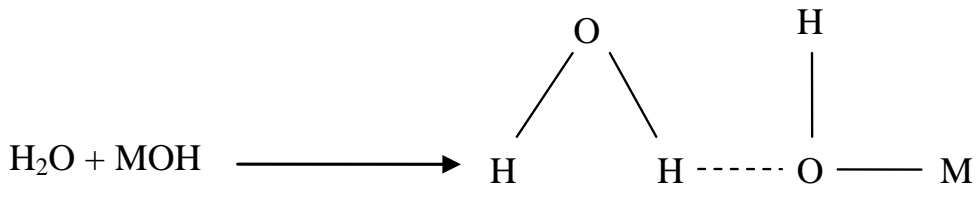

Hydrogen bonded

Scheme 4. Formation of hydrogen bonded.
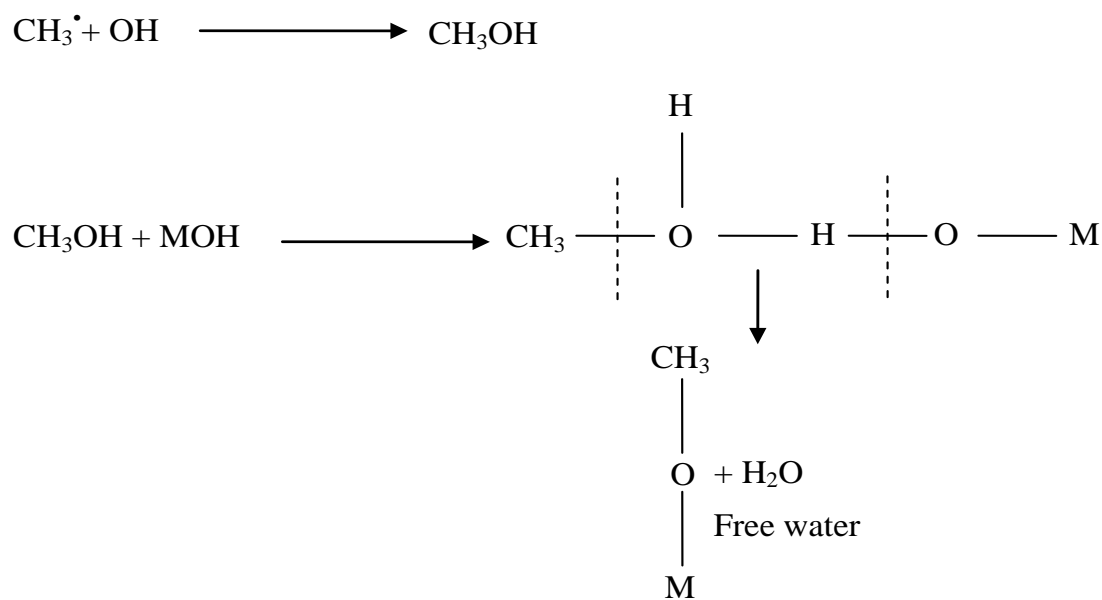

Scheme 5. Formation of free water.

bands at 2355 and $2331 \mathrm{~cm}^{-1}$ which have been assigned to an asymmetrically disubstituted alkyne conjugated to a carbonyl group. Doubling the frequency is an indication of conjugated (-C=C-) groups [61] [62] [63].

The mechanism of formation of the alkyne entity is envisaged to take place through ethylene formation as is represented by the following:

1) First possibility is the dissociation of the alkoxy group into $\left(\mathrm{CO}_{2}\right)$ and $(\mathrm{CO})$ which in turn form surface carbon $\left(\mathrm{C}_{\mathrm{s}}\right)$ and oxygen leading to the formation of the acetylenic surface species [64] (Scheme 6).

2) Moreover, the $\equiv \mathrm{C}-\mathrm{H}$ vibration stretch at $3000 \mathrm{~cm}^{-1}$ region has not been observed which rule out such a schematic mechanism.

Iii formation of ethylene according to the following mechanism [65] [66] (Scheme 7).

Ethylene could also be formed by the reaction of $\left(\mathrm{CH}_{3}{ }^{\circ}\right)$ radicals with the surface to form carbon radicals which then combines to yield $\left(\mathrm{C}_{2} \mathrm{H}_{4}\right)$. The latter is 


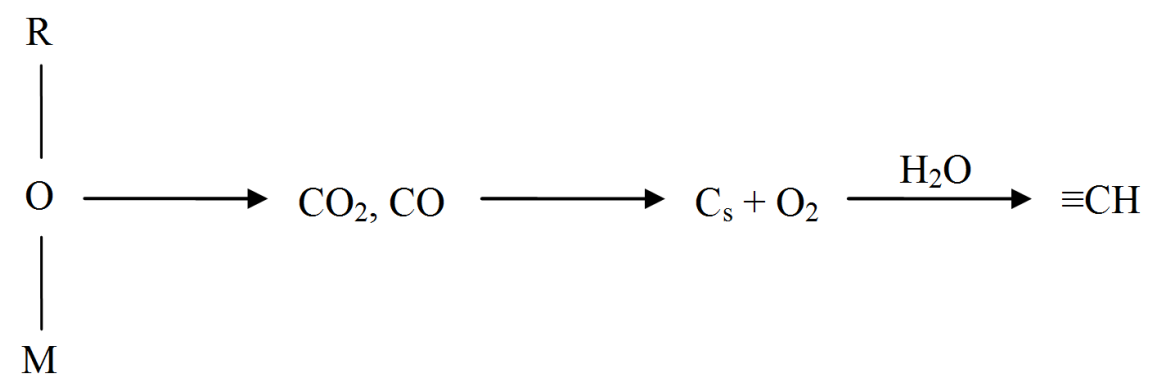

Scheme 6. Dissociation of alkoxy group.

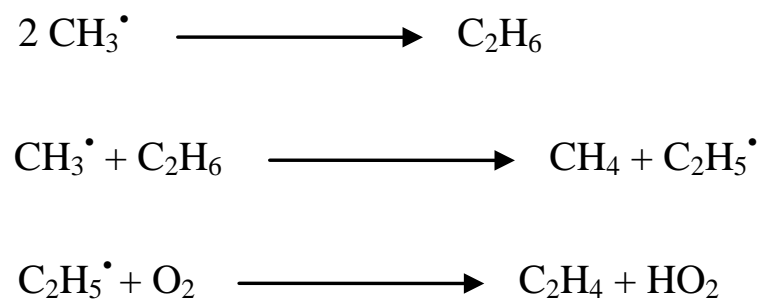

Scheme 7. Formation of ethylene.

dehydrogenated to form an alkyl acetylide surface species, e.g. (Scheme 8).

It is worth noting that ethylene adsorbs irreversibly on clear platinum with dissociation into an acetylenic species and mobile hydrogen [67].

Also, ethylene is reported to dehydrogenate upon adsorption on platinum (III) surface, transforming into a stable acetylenic structure [68]. Further, structural evidence has been reported for the formation of the ethyldyne group on platinum (III) [69].

\subsection{0 - $1800 \mathrm{~cm}^{-1}$ Region}

In the $2000-1800 \mathrm{~cm}^{-1}$ spectral region, very weak absorption at 1989, 1942, $1919,1889,1866$, and $1830 \mathrm{~cm}^{-1}$ was observed. In this area, combination and overtone bands appear. Their pattern is characteristic of the substitution pattern of the ring, e.g. indication of the monosubstituted ring.

However, no assignments have been attempted and the bands could be considered either as:

1) Combination and overtones,

or

2) Noise

\subsection{0 - $1100 \mathrm{~cm}^{-1}$ Region}

The $1800-1100 \mathrm{~cm}^{-1}$ region of the spectra is a wide range and within its range many absorption bands of different compounds and structures appear, e.g. oxalates, carbonates, nitrates, aldehydes, ketones, alcohols and aromatic hydrocarbons, etc.

Table 2 presents the infrared absorption bands in the spectral region concerned with tentative group assignments. 


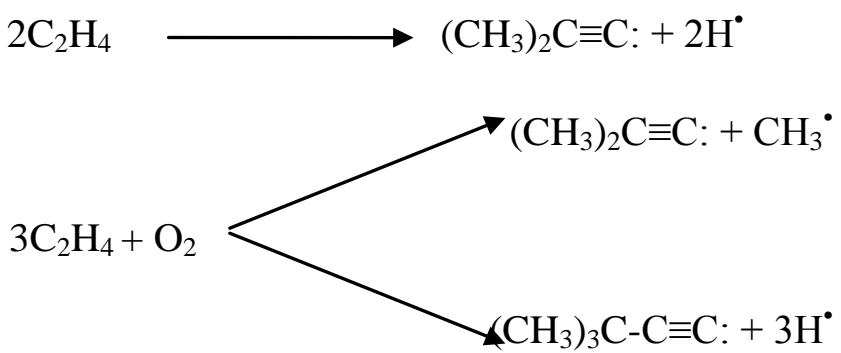

Scheme 8. Dehydrogenation of $\mathrm{C}_{2} \mathrm{H}_{4}$.

Table 2. I.R. absorption bands and tentative assignments.

\begin{tabular}{|c|c|}
\hline Absorption bands $\mathrm{cm}^{-1}$ & Group Assignment (tentative) \\
\hline 1795 & \\
\hline 1772 & $\equiv \mathrm{C}-\mathrm{C} \equiv, \mathrm{C}=\mathrm{O}$ stretch, (Carbonyl Carboxylic acids) \\
\hline 1736 & $v(\mathrm{C}=\mathrm{O})$ stretch, \\
\hline 1695 & (carboxylic acid, Saturated aliphatic aldehydes, Ketones) \\
\hline 1648 & $\mathrm{C}=\mathrm{C}$ stretch, alkenes \\
\hline 1537 & $v_{\text {as }} \mathrm{COO}$ (Carboxylate ions) \\
\hline 1513 & C-C stretch (in ring), aromatics \\
\hline 1460 & $\mathrm{CH}_{3}$ or $\mathrm{CH}_{2}$ (Methyl bend or scissoring) \\
\hline 1425 & $v_{\text {as }} \mathrm{COO}, \mathrm{O}-\mathrm{H}$ bending \\
\hline 1396 & $\mathrm{CH}_{3}$ or $\mathrm{CH}_{2}$ \\
\hline 1337 & $\begin{array}{c}\mathrm{CH}_{2} \text { adjacent to }-\mathrm{C} \equiv \mathrm{C}-\text {, or } \mathrm{O}-\mathrm{H} \text { bending of Alcohols and } \\
\text { Phenols }\end{array}$ \\
\hline 1313 & C-O stretch, alcohols, carboxylic acids, esters, ethers. \\
\hline 1266 & $\mathrm{C}-\mathrm{O}, \mathrm{O}-\mathrm{H}$ ( $\mathrm{H}$ bonded) \\
\hline 1166 & $\mathrm{CH}_{2}$ wag. \\
\hline 1114 & C-O Stretch, Alcohol, Ethers, Esters. \\
\hline 1067 & $\mathrm{C}-\mathrm{C}$, or $-\mathrm{C}=\mathrm{C} \backslash=\mathrm{C}-($ Allenes $)$ \\
\hline 1031 & Methoxy-metal, or Polydentate Carbonates \\
\hline
\end{tabular}

The I.R. band at $1742 \mathrm{~cm}^{-1}$ has been tentatively assigned to $v(\mathrm{C}=\mathrm{O})$ stretch and the $1402 \mathrm{~cm}^{-1}$ band is assigned to the $\mathrm{CH}_{2}$ scissors mode of the methylene group. The $1337 \mathrm{~cm}^{-1}$ and $1313 \mathrm{~cm}^{-1}$ bands are due to $\mathrm{CH}_{2}$ deformation. The bands at 1460 and $1390 \mathrm{~cm}^{-1}$ have been tentatively assigned to $\delta_{\text {as }}\left(\mathrm{CH}_{3}\right)$ and $\delta_{\text {sy }}$ $\left(\mathrm{CH}_{3}\right)$ of a t-butyl group [56] [70] [71] [72].

\subsection{Below $1100 \mathrm{~cm}^{-1}$ Region}

In the region of the spectra below $1100 \mathrm{~cm}^{-1}$ several weak bands appear, mainly the band at 667 and $508 \mathrm{~cm}^{-1}$. The former band at $667 \mathrm{~cm}^{-1}$ could be assigned to chemisorbed $\mathrm{CO}_{2}$, while the later band at $508 \mathrm{~cm}^{-1}$ might tentatively be assigned to [Ln -O-] stretch. 
Upon evacuation at higher temperatures, the $v_{\text {str }}(-\mathrm{C} \equiv \mathrm{C}-)$ and $667 \mathrm{~cm}^{-1}$ absorption bands diminish, while $2965,2961,2855 \mathrm{~cm}^{-1}$ increases, and the $(\mathrm{OH})$ stretching vibration at $\sim 3450 \mathrm{~cm}^{-1}$ builds up. The $1740 \mathrm{~cm}^{-1}$ disappears and the strong bands in the $1550-1000 \mathrm{~cm}^{-1}$ appear.

The complement of such results could be integrated and interpreted in terms of formation of several independent species resulting from the breakdown of the originally formed surface species.

Evidence of ring formation has been found in the 667 and $880 \mathrm{~cm}^{-1}$ bands which are assigned to out of plane $(\mathrm{C}-\mathrm{H})$ band in the mono-substituted benzene ring, while the bands in the $1000 \mathrm{~cm}^{-1}$ region could be assigned to $(\mathrm{C}-\mathrm{H})$ in the plane band. However, the (- $\mathrm{C} \equiv \mathrm{C}-)$ stretches could be assigned to the bands at 1513,1537 and $1551 \mathrm{~cm}^{-1}$.

Mono-substitution of the benzene ring (formation of aromatic compounds) is further indicated by the $1800-2000 \mathrm{~cm}^{-1}$ weak absorption bands.

A methylene group could be seen, and the band at $1402 \mathrm{~cm}^{-1}$ is tentatively assigned to the $\left(\mathrm{CH}_{2}\right)$ scissors mode of the methylene group, while the $1337 \mathrm{~cm}^{-1}$ and the $1313 \mathrm{~cm}^{-1}$ bands are due to $\left(\mathrm{CH}_{2}\right)$ deformation.

\section{Conclusion}

This study showed that the oxidative Coupling of methane (OCM) occurs through homogeneous and heterogeneous catalysis reactions that begin by extracting hydrogen of methane in gas phase by activated oxygen on the surface of the catalyst and get methyl radical $\mathrm{CH}_{3}{ }^{\circ}$. On the other hand (together with $\mathrm{H}_{2} \mathrm{O}$ co-production), mainly for the production of ethylene $\mathrm{C}_{2} \mathrm{H}_{6}$, and the formation of ethylene $\mathrm{C}_{2} \mathrm{H}_{4}$ through both heterogeneous and heterogeneous reactions, while Oxygenated carbon products from $\mathrm{CO}_{\mathrm{x}}$ (i.e., $\mathrm{CO}_{2}$ and $\mathrm{CO}$ ) consist mainly of oxidation of those gaseous phases of hydrocarbons on the catalyst surface. For all the catalysts the conversion increases relatively with increasing the reaction temperature.

\section{Acknowledgements}

The author is much grateful to King Abdulalziz City for Science and Technology (KACST), Riyadh, Saudi Arabia for the valuable and continues scientific and moral support.

\section{References}

[1] Amenomiya, Y., Birss, V.I., Galuszka, J. and Sanger, A.R. (1990) Conversion of Methane by Oxidative Coupling. Catalysis Reviews, 32, 163-227. https://doi.org/10.1080/01614949009351351

[2] Tan, X., Pang, Z., Gu, Z. and Liu, S. (2007) Catalytic Perovskite Hollow Fibre Membrane Reactors for Methane Oxidative Coupling. Journal of Membrane Science, 302, 109-114. https://doi.org/10.1016/j.memsci.2007.06.033

[3] Nouralishahi, A., Pahalavanzadeh, H. and Daryan, J.T. (2008) Determination of Optimal Temperature Profile in an OCM Plug Flow Reactor for the Maximizing of 
Ethylene Production. Fuel Processing Technology, 89, 667-677.

https://doi.org/10.1016/j.fuproc.2007.12.004

[4] Guo, X., Fang, G., Li, G., Ma, H., Fan, H., Yu, L., Ma, C., Wu, X., Deng, D., Wei, M., Tan, D., Si, R., Zhang, S., Li, J., Sun, L., Tang, Z., Pan, X. and Bao, X. (2014) Direct, No-Oxidative Conversion of Methane to Ethylene, Aromatics, and Hydrogen. Science, 344, 616-619. https://doi.org/10.1126/science.1253150

[5] Schwach, P., Pan, X. and Bao, X. (2017) Direct Conversion of Methane to Value-Added Chemicals over Heterogeneous Catalysts: Challenges and Prospects. Chemical Reviews, 117, 8497-8520. https://doi.org/10.1021/acs.chemrev.6b00715

[6] Tang, P., Zhu, Q., Wu, Z. and Ma, D. (2014) Methane Activation: The Past and Future. Energy \& Environmental Science, 7, 2580-2591. https://doi.org/10.1039/C4EE00604F

[7] Keller, G.E. and Bhasin, M.M. (1982) Synthesis of Ethylene via Oxidative Coupling of Methane. Journal of Catalysis, 73, 9-19. https://doi.org/10.1016/0021-9517(82)90075-6

[8] Mathur, B.C. and Viswanath, D.S. (1974) Catalytic Vapor-Phase Oxidation of P-Xylene over Tin Vanadate. Journal of Catalysis, 32, 1.

https://doi.org/10.1016/0021-9517(74)90152-3

[9] Solymosi, F., Tombàcz, I. and Kutsàn, G. (1985) Partial Oxidation of Methane by Nitrous Oxide over $\mathrm{Bi}_{2} \mathrm{O}_{3}-\mathrm{SnO}_{2}$. Journal of the Chemical Society, Chemical Communications, No. 20, 1455-1456. https://doi.org/10.1039/C39850001455

[10] Argent, A. and Harrison, P.G. (1986) The Selective Dehydrogenation of Ethane over $\mathrm{SnO}_{2}-\mathrm{P}_{2} \mathrm{O}_{5}$ Catalysts. Journal of the Chemical Society, Chemical Communications, No. 14, 1058. https://doi.org/10.1039/C39860001058

[11] Metcalfe, W.K., Burke, S.M., Ahmed, S.S. and Curran, H.J. (2013) A Hierarchical and Comparative Kinetic Modeling Study of $\mathrm{C}_{1}-\mathrm{C}_{2}$ Hydrocarbon and Oxygenated Fuels. International Journal of Chemical Kinetics, 45, 638-675.

https://doi.org/10.1002/kin.20802

[12] Shu, Y. and Ichikawa, M. (2001) Catalytic Dehydrocondensation of Methane towards Benzene and Naphthalene on Transition Metal Supported Zeolite Catalysts: Templating Role of Zeolite Micropores and Characterization of Active Metallic Sites. Catalysis Today, 71, 55-67. https://doi.org/10.1016/S0920-5861(01)00440-0

[13] Ji, S.-F., Xiao, T.-C., Li, S.-B., Xu, C.-Z., Hou, R.-L., Coleman, K.S. and Green, M.L.H. (2002) The Relationship between the Structure and the Performance of $\mathrm{Na}-\mathrm{W}-\mathrm{Mn} / \mathrm{SiO}_{2}$ Catalysts for the Oxidative Coupling of Methane. Applied Catalysis $A$, 225, 271-284. https://doi.org/10.1016/S0926-860X(01)00864-X

[14] Ward, M.B., Lin, M.J. and Lunsford, J.H. (1977) The Oxidative Dehydrogenation of Ethane by Nitrous Oxide over Molybdenum Oxide Supported on Silica Gel. Journal of Catalysis, 50, 306. https://doi.org/10.1016/0021-9517(77)90040-9

[15] Blunden, S.J. and Hill, P.A. (1985) The Industrial Uses of Tin Chemicals. The Royal Society of Chemistry, London.

[16] Zhang, M., Feng, Y., Ke, L., Wu, J. and Zhao, O. (2015) A Review of Catalysts for Oxidative Coupling of Methane. Petrochemical Technology, 44, 401-408.

[17] Külah, E., Marot, L., Steiner, R., et al. (2017) Surface Chemistry of Rare-Earth Oxide Surfaces at Ambient Conditions: Reactions with Water and Hydrocarbons. Scientific Reports, 7, Article No. 43369. https://doi.org/10.1038/srep43369

[18] Sazonov, L.A. and Artmonov, E.V. (1968) The Mechanism of CO Oxidation over Lanthanum Oxide. Journal of Catalysis, 10, 207. 
https://doi.org/10.1016/0021-9517(68)90197-8

[19] Araujo, J.C.S., Zanchet, D., Rinaldi, R., Schuchardt, U., Hori, C.E., Fierro, J.L.G. and Bueno, J.M.C. (2008) The Effects of $\mathrm{La}_{2} \mathrm{O}_{3}$ on the Structural of $\mathrm{La}_{2} \mathrm{O}_{3}-\mathrm{Al}_{2} \mathrm{O}_{3}$ Prepared by the Sol-Gel Method and on the Catalytic Performance of $\mathrm{Pt} / \mathrm{La}_{2} \mathrm{O}_{3}-\mathrm{Al}_{2} \mathrm{O}_{3}$ towards Steam Reforming and Partial Oxidation of Methane. Applied Catalysis $B$, 84, 552-562. https://doi.org/10.1016/j.apcatb.2008.05.011

[20] Lunsford, J.H. (2000) Catalytic Conversion of Methane to More Useful Chemicals and Fuel: The Challenge for the 21st Century. Catalysis Today, 63, 165-174. https://doi.org/10.1016/S0920-5861(00)00456-9

[21] Campbell, K.D., Zhang, H. and Lunsford, J.H. (1988) Methane Activation by the Lanthanide Oxide. The Journal of Physical Chemistry, 92, 750-753. https://doi.org/10.1016/S0920-5861(00)00456-9

[22] Palermo, A., Vazquez, J.P.H., Lee, A.F., Tikhov, M.S. and Lambert, R.M. (1998) Critical Influence of the Amorphous Silica-to-Cristobalite Phase Transition on the Performance of $\mathrm{Mn} / \mathrm{Na}_{2} \mathrm{WO}_{4} / \mathrm{SiO}_{2}$ Catalysts for the Oxidative Coupling of Methane. Journal of Catalysis, 177, 259-266. https://doi.org/10.1006/jcat.1998.2109

[23] Lee, S.H., Jung, J.-S., Joo, J.-U., Myung, N.-S., Jun, J.-H. and Choi, J.-G. (2002) Catalytic Behavior of $\mathrm{O}_{2}$-Pretreated $\mathrm{Ni}_{3}\left(\mathrm{SbTe}_{3}\right)_{2}$ Catalyst in Oxidative Coupling of Methane. Applied Catalysis A, 237, 91-101. https://doi.org/10.1006/jcat.1998.2109

[24] Lin, Y.Z., Sun, J., Yi, J., Lin, J.D., Chen, H.B. and Liao, D.W. (2002) Energetics of Chemisorption and Conversion of Methane on Transition Metal Surfaces. Journal of Molecular Structure: THEOCHEM, 587, 63-71. https://doi.org/10.1016/S0166-1280(02)00097-0

[25] Wang, L., Tao, L., Xie, M., Xu, G., Huang, J. and Xu, Y. (1993) Dehydrogenation and Aromatization of Methane under Non-Oxidizing Condition. Catalysis Letters, 21, 35-41. https://doi.org/10.1007/BF00767368

[26] Driscoll, D.J., Martir, W., Wang, J.X. and Lunsford, J.H. (1985) Formation of Gas-Phase Methyl Radicals over MgO. Journal of the American Chemical Society, 107, 58-63. https://doi.org/10.1021/ja00287a011

[27] Wu, J., Zhang, H., Qin, S. and Hu, C. (2007) La-Promoted $\mathrm{Na}_{2} \mathrm{WO}_{4} / \mathrm{Mn} / \mathrm{SiO}_{2}$ Catalysts for the Oxidative Conversion of Methane Simultaneously to Ethylene and Carbon Monoxide. Applied Catalysis A, 323, 126-134.

https://doi.org/10.1016/j.apcata.2007.02.009

[28] Otsuka, K., Jinno, K. and Morikawa, K. (1986) Active and Selective Catalysts for the Synthesis of $\mathrm{C}_{2} \mathrm{H}_{4}$ and $\mathrm{C}_{2} \mathrm{H}_{6}$ via Oxidative Coupling of Methane. Journal of Catalysis, 100, 353. https://doi.org/10.1016/0021-9517(86)90102-8

[29] Zeng, Y., Akin, F.T. and Lin, Y.S. (2001) Oxidative Coupling of Methane on Fluorite-Structured Samarium-Yttrium-Bismuth Oxide. Applied Catalysis A, 213, 33-45. https://doi.org/10.1016/S0926-860X(00)00877-2

[30] Dedov, A.G., Loktey, A.S., Aboukais, A., Lamonier, J.-F. and Filimonov, I.N. (2003) Oxidative Coupling of Methane Catalyzed by Rare Earth Oxides Unexpected Synergistic Effect of the Oxide Mixtures. Applied Catalysis, 245, 209-220. https://doi.org/10.1016/S0926-860X(00)00877-2

[31] Kus, S. and Taniewski, M. (2002) The Effect of Some Impurities on the Basicity of $\mathrm{MgO}$ Tested by the Transformation of 2-Butanol and on Its Catalytic Performance in Oxidative Coupling of Methane. Fuel Processing Technology, 76, 41-49. https://doi.org/10.1016/S0378-3820(02)00018-8

[32] Karakaya, C. and Kee, R.J. (2016) Progress in the Direct Catalytic Conversion of 
Methane to Fuels and Chemicals. Progress in Energy and Combustion Science, 55, 60-97. https://doi.org/10.1016/j.pecs.2016.04.003

[33] Alexiadis, V.I., Chaar, M., van Veen, A., Muhler, M., Thybaut, J.W. and Marin, G.B. (2016) Quantitative Screening of an Extended Oxidative Coupling of Methane Catalyst Library. Applied Catalysis B: Environmental, 199, 252-259.

https://doi.org/10.1016/j.apcatb.2016.06.019

[34] Martin, G.A., Bernal, S., Perrichon, V. and Mirodatos, C. (1992) Hetero-Homogeneous Processes Involved in Oxidative Conversion of Methane, Ethane and Hydrocarbon Mixtures over Basic Oxides. Catalysis Today, 13, 487-494. https://doi.org/10.1016/0920-5861(92)80069-Y

[35] Tong, Y., Rosynek, M.P. and Lansford, J.H. (1989) Secondary Reactions of Methyl Radicals with Lanthanide Oxides: Their Role in the Selective Oxidation of Methane. The Journal of Physical Chemistry, 93, 2896-2898. https://doi.org/10.1021/j100345a012

[36] Tan, P. (2016) Active Phase, Catalytic Activity, and Induction Period of Fe/Zeolite Material Innon-Oxidative Aromatization of Methane. Journal of Catalysis, 338, 21-29. https://doi.org/10.1016/j.jcat.2016.01.027

[37] Malekzadeh, A., Khodadadi, A., Abedini, M., Amini, M., Bahramian, A. and Dalai, A.K. (2001) Correlation of Electrical Properties and Performance of OCM $\mathrm{MOx} / \mathrm{Na}_{2} \mathrm{WO}_{4} / \mathrm{SiO}_{2}$ Catalysts. Catalysis Communications, 2, 241-247. https://doi.org/10.1016/j.jcat.2016.01.027

[38] Takenake, S., Kaburagi, T., Yamanka, I. and Otsuka, K. (2001) Oxidative Coupling of Methane over Li+-Added $\mathrm{Y}_{2} \mathrm{O}_{3}$ Catalyst Prepared from $\mathrm{Y}(\mathrm{OH})_{3}$. Catalysis Today, 71, 31-36. https://doi.org/10.1016/S0920-5861(01)00443-6

[39] $\mathrm{Au}$, C.T., Chen, K.D. and Ng, C.F. (1998) The Modification of $\mathrm{Gd}_{2} \mathrm{O}_{3}$ with $\mathrm{BaO}$ for the Oxidative Coupling of Methane Reactions. Applied Catalysis A, 170, 81-92. https://doi.org/10.1016/S0926-860X(98)00051-9

[40] Schwach, P., Hamilton, N., Eichelbaum, M., Thum, L., Lunkenbein, T., Schlögl, R. and Trunschke, A. (2015) Structure Sensitivity of the Oxidative Activation of Methane over MgO Model Catalysts: I. Kinetic Study. Journal of Catalysis, 329, 560-573. https://doi.org/10.1016/j.jcat.2015.05.007

[41] Choudhary, V.R. and Rane, V.H. (1991) Acidity/Basicity of Rare-Earth Oxides and Their Catalytic Activity in Oxidative Coupling of Methane to $\mathrm{C}_{2}$-Hydrocarbons. Journal of Catalysis, 130, 411-422. https://doi.org/10.1016/0021-9517(91)90124-M

[42] Schwach, P., Hamilton, N., Eichelbaum, M., Thum, L., Lunkenbein, T., Schlögl, R. and Trunschke, A. (2015) Structure Sensitivity of the Oxidative Activation of Methane over MgO Model Catalysts: II. Nature of Active Sites and Reaction Mechanism. Journal of Catalysis, 329, 574-587. https://doi.org/10.1016/j.jcat.2015.05.008

[43] Iami, H. and Tagawa, T. (1990) Oxidative Coupling of Methane over Amorphous $\mathrm{LnAlO}_{3}$ Catalysts. Zeitschrift fur Physikalische Chemie Neue Folge, 167, 105-112. https://doi.org/10.1524/zpch.1990.167.Part_1.105

[44] Tagawa, T. and Imai, H. (1988) Mechanistic Aspects of Oxidative Coupling of Methane over LaAlO. Journal of the Chemical Society, Faraday Transactions, 84, 923-929. https://doi.org/10.1524/zpch.1990.167.Part_1.105

[45] Polteva, T.V., Venskovskii, N.U., Kaleva, G.M., Mosunov, A.V., Prutchenko, S.G. and Politova, E.D. (1994) Effect of Electronic Properties of Catalysts for the Oxidative Coupling of Methane on Their Selectivity and Activity. Catalysis Reviews-Science and Engineering, 36, 507-556.

https://doi.org/10.1080/01614949408009470 
[46] Vishnyakov, A.V., Korshunova, I.A., Kochurikhin, V.E. and Sal'nikova, L.S. (2010) Catalytic Activity of Rare Earth Oxides in Flameless Methane Combustion. Kinetics and Catalysis, 51, 273-278. https://doi.org/10.1134/S0023158410020163

[47] Papa, F., Luminita, P., Osiceanu, P., Birjega, R., Akane, M. and Balint, I. (2011) Acid-Base Properties of the Active Sites Responsible for $\mathrm{C}_{2+}$ and $\mathrm{CO}_{2}$ Formation over MO- $\mathrm{Sm}_{2} \mathrm{O}_{3}(\mathrm{M}=\mathrm{Zn}, \mathrm{Mg}$, Ca and $\mathrm{Sr})$ Mixed Oxides in OCM Reaction. Journal of Molecular Catalysis A: Chemical, 346, 46-54.

https://doi.org/10.1016/j.molcata.2011.06.008

[48] Elkins, T.W., Roberts, S.J. and Hagelin-Weaver, H.E. (2016) Effects of Alkali and Alkaline-Earth Metal Dopants on Magnesium Oxide Supported Rare-Earth Oxide Catalysts in the Oxidative Coupling of Methane. Applied Catalysis A: General, 528, 175-190. https://doi.org/10.1016/j.apcata.2016.09.011

[49] Lee, M.-J., Jun, J.-H., Jung, J.-S., Kim, Y.-R. and Lee, S.-H. (2005) Bull, Catalytic Activities of Perovskite-Type $\mathrm{LaBO}_{3}(\mathrm{~B}=\mathrm{Fe}, \mathrm{Co}, \mathrm{Ni}$ ) Oxides for Partial Oxidation of Methane. Bulletin of the Korean Chemical Society, 26, 1591-1596.

https://doi.org/10.5012/bkcs.2005.26.10.1591

[50] Urdă, A., Popescu, I., Cacciaguerra, T., Tanchoux, N., Tichit, D. and Marcu, I.-C. (2013) Total Oxidation of Methane over Rare Earth Cation-Containing Mixed Oxides Derived from LDH Precursors. Applied Catalysis A: General, 464-465, 20-27. https://doi.org/10.1016/j.apcata.2013.05.012

[51] Liang, Y., Li, Z., Nourdine, M., Shahid, S. and Takanabe, K. (2014) Methane Coupling Reaction in an Oxy-Steam Stream through an $\mathrm{OH}$ Radical Pathway by using Supported Alkali Metal Catalysts. ChemCatChem, 6, 1245-1251.

[52] Shen, S., Hou, R., Ji, W., Yan, Z. and Ding, X. (1993) In Situ FT-IR Study of $\mathrm{O}_{2}$, CO, $\mathrm{CO}_{2}, \mathrm{CH}_{4}$ and $\mathrm{C}_{2} \mathrm{H}_{4}$ Adsorption or Reaction on the $\mathrm{La}_{2} \mathrm{O}_{3} \mathrm{MgO}$ Catalyst. Studies in Surface Science and Catalysis, 75, 1527-1530. https://doi.org/10.1016/S0167-2991(08)64471-7

[53] Maitra, A.M., Campbell, I. and Tyler, R.J. (1992) Influence of Basicity on the Catalytic Activity for Oxidative Coupling of Methane. Applied Catalysis A, General, 85, 27-46. https://doi.org/10.1016/0926-860X(92)80127-X

[54] Matar, S., Marrbach, M.J. and Tayim, H.A. (1989) Catalysis in Petrochemical Processes. Klumer Academic Publishers, 184.

https://doi.org/10.1007/978-94-009-1177-2

[55] Banwell, C.N. (1972) Fundamental of Molecular Spectroscopy. 2nd Edition, McGraw-Hill Co., New York, 105.

[56] Lucchesi, P.J., Carter, J.L. and Yates, D.J.C. (1962) An Infrared Study of the Chemisorption of Ethylene on Aluminum Oxide. The Journal of Physical Chemistry B, 66, 1451-1456. https://doi.org/10.1021/j100814a018

[57] Wang, Y., Zheng, W., Chen, F. and Zhan, X. (2008) Mechanistic Study of Propylene Oxidation over a Bi-Molybdate Catalyst by in Situ DRIFTS and Probe Molecules. Applied Catalysis A, 351, 75-81. https://doi.org/10.1016/j.apcata.2008.08.029

[58] Bellamy, L.J. (1963) The Infrared Spectra of Complex Molecules. London.

[59] Lui, H.F., Lin, R.S., Kiew, K.Y., Johnson, R.E. and Lunsford, J.H. (1984) Partial Oxidation of Methane by Nitrous Oxide over Molybdenum on Silica. Journal of the American Chemical Society, 106, 4117-4121. https://doi.org/10.1021/ja00327a009

[60] Wang, L.H., Yi, X.D., Weng, W.Z. and Wan, H.L. (2008) In Situ IR and Pulse Reaction Studies on the Active Oxygen Species over $\mathrm{SrF}_{2} / \mathrm{Nd}_{2} \mathrm{O}_{3}$ Catalyst for Oxidative Coupling of Methane. Catalysis Today, 131, 135-139. 
https://doi.org/10.1016/j.cattod.2007.10.014

[61] Henne, A.L. and Nager, M. (1951) Trifluoropropyne. Journal of the American Chemical Society, 73, 1042-1043. https://doi.org/10.1021/ja01147a047

[62] Henne, A.L. and Finnegan, W.G. (1949) Perfluro-2-Butyne and Its Hydrogenation Products. Journal of the American Chemical Society, 71, 298-300. https://doi.org/10.1021/ja01169a080

[63] Gensler, W.J., Mahadeven, A.P. and Casella, J. (1956) Preparation and Constitution of Nonadiyne-1,4. Journal of the American Chemical Society, 78, 163. https://doi.org/10.1021/ja01582a046

[64] Allen, J.L.H., Meakins, G.D. and Whiting, M.C. (1955) Researches on Acetylenic Compounds. Part L. The Infrared Absorption of Some Conjugated Ethylenic and Acetylenic Systems. Journal of the Chemical Society, 1874-1881. https://doi.org/10.1039/jr9550001874

[65] Cook, C.L., Jones, E.R.H. and Whiting, M.C. (1952) Researches on Acetylenic Compounds. Part XXXIX. General Routes to Aliphatic Polyacetylenic Hydrocarbons and Glycols. Journal of the Chemical Society, 2883-2891. https://doi.org/10.1039/jr9520002883

[66] Kotanigawa, T., Shimokawa, K. and Yamamoto, M. (1982) Role of Water Vapour in the Carbon Monoxide-Water Reaction System on an Iron Catalyst. Journal of the Chemical Society, Chemical Communications, 29-30.

[67] Chiu-Hsun, L., Campbell, K.D., Xiang, W.J. and Lunsford, J.H. (1986) Oxidative Dimerization of Methane over Lanthanum Oxide. The Journal of Physical Chemistry, 90, 534-537. https://doi.org/10.1021/j100276a004

[68] Sun, J., Thybaut, J.W. and Marin, G.B. (2008) Microkinetics of Methane Oxidative Coupling. Catalysis Today, 137, 90-102. https://doi.org/10.1016/j.cattod.2008.02.026

[69] Smith, D.L. and Merrill, R.P. (1970) Ethylene Adsorption on Pt (111). The Journal of Chemical Physics, 52, 5861-5872. https://doi.org/10.1063/1.1672870

[70] Stair, P.C. and Somorjai, G.A. (1977) The Adsorption of Hydrocarbons on Platinum Studied by Low-Energy Electron Diffraction Intensities. The Ordered $(2 \times 2)$ Overlayers of Acetylene and Ethylene on the (111) Crystal Face of Platinum. The Journal of Chemical Physics, 66, 2036-2044. https://doi.org/10.1063/1.434162

[71] Kesmodel, L.L., Dubois, L.H. and Somojai, G.A. (1978) Dynamical LEED Study of $\mathrm{C}_{2} \mathrm{H}_{2}$ and $\mathrm{C}_{2} \mathrm{H}_{4}$ Chemisorption on $\mathrm{Pt}(111)$ : Evidence for the Ethylidyne Group. The Journal of Physical Chemistry Letters, 56, 267-271. https://doi.org/10.1063/1.434162

[72] Harrison, P.G. and Thornton, E.W. (1976) Part 7 An Infrared Study of the Chemisorption and Oxidation of Organic Lewis Base Molecules on Tin (IV) Oxide. Journal of the Chemical Society, 72, 1484-1491. https://doi.org/10.1063/1.434162 